\title{
Staged management of a congenital nevus of the breast and abdomen presenting in a female infant
}

\author{
Ryan M Neinstein $\mathrm{BSC}^{1}$, Gregory $\mathrm{H}$ Borschel $\mathrm{MD}^{2}$, Ronald M Zuker MD FRCSC FACS ${ }^{2}$
}

\begin{abstract}
RM Neinstein, GH Borschel, RM Zuker. Staged management of a congenital nevus of the breast and abdomen presenting in a female infant. Can J Plast Surg 2006;14(2):91-93.

The management of congenital melanocytic nevi is controversial. The authors describe their management of a congenital nevus covering the breast and abdomen of a one-month-old girl over a 16-year period. To prevent damage to the developing breast, a staged approach was used. The nevus over the abdomen was resected first at six years of age and the remaining portion was removed after breast development was complete at 16 years of age. The breast defect was resurfaced with a full thickness skin graft from the groin. The patient was pleased with the postoperative result. This staged approach allowed an optimized aesthetic result.
\end{abstract}

Key Words: Congenital melanocytic nevus; Pediatric breast anomaly; Pediatric plastic surgery; Tissue expansion

\section{Traitement par étapes d'un naevus congénital des seins et de l'abdomen chez un nourrisson de sexe féminin}

Le traitement des naevus congénitaux à mélanocytes ne fait pas l'unanimité. Les auteurs décrivent, dans le présent article, la manière dont ils s'y sont pris pour traiter un naevus congénital des seins et de l'abdomen chez une petite fille de un mois, et ce, sur une période de 16 ans. Ils ont eu recours à une approche par étapes pour éviter de nuire au développement des seins. Les médecins ont d'abord procédé à la résection de la partie abdominale du naevus, à l'âge de six ans, puis ont excisé le reste une fois que les seins eurent atteint leur développement complet, à l'âge de seize ans. La perte de substance du sein a été comblée par un greffon de peau totale, prélevé à l'aine. La patiente est satisfaite des résultats postopératoires, et l'approche par étapes a permis une optimisation des résultats esthétiques.
C

Congenital melanocytic nevi $(\mathrm{CMN})$ are neuroectodermal malformations containing melanocytes and, occasionally, neural elements (1). The major goals of congenital nevus removal are to achieve a satisfactory cosmetic result and to prevent untoward psychosocial and developmental sequelae. It is sometimes very difficult to eliminate the disfiguring nevus without introducing secondary cosmetic deformities.

The following is a description of the treatment of a congenital nevus involving the breast and abdomen. We wanted to minimize the potential for an iatrogenic contour deformity during breast development by respecting the boundaries of the developing breast bud (2).

\section{CASE PRESENTATION}

A one-month-old girl of South Asian ancestry presented to the Hospital for Sick Children (Toronto, Ontario) plastic surgery clinic with a large congenital nevus. A large pigmented lesion was present over the right chest and abdomen (Figure 1). Management options were discussed with the parents. The authors planned to perform serial examinations every six months until the patient reached an age where surgical management was deemed appropriate.

At six years of age, a three-stage surgical approach was planned. Stage 1 (placement of a $15 \mathrm{~cm} \times 5 \mathrm{~cm}$ tissue expander) and stage 2 (excision of the abdominal component of the nevus and coverage with expanded skin) were both performed at six years of age (Figures $2 \mathrm{~A}$ and $2 \mathrm{~B}$ ). Due to concerns with damaging the developing breast bud, it was decided to leave the thoracic component of the nevus unresected until breast maturity was complete. The inferior part of the nevus appeared to be able to be excised with tissue expansion of the adjacent abdominal skin.

She was followed in the clinic until 16 years of age, when she decided to undergo excision of the remaining nevus in stage 3. She had completed breast development at this point. The remaining nevus from the right breast was removed and a full-thickness skin graft from the left groin was used to resurface the defect. Her recovery was uneventful and she was satisfied with the cosmetic result (Figures $3 \mathrm{~A}$ and $3 \mathrm{~B}$ ).

\section{DISCUSSION}

CMN are present in $1 \%$ of newborns (3). Sometimes the nevi are not seen on initial physical examination because the pigment has not yet become visible. The nevi usually become clinically detectable within the first two years of life and are known as tardive CMNs if they follow this course (4). CMNs have been classified according to size. Nevi smaller than $1.5 \mathrm{~cm}$ in greatest diameter are classified as small, those measuring between $1.5 \mathrm{~cm}$ and $19.9 \mathrm{~cm}$ are medium, and those greater than $20 \mathrm{~cm}$ are classified as large. Nevi larger than $50 \mathrm{~cm}$ are termed 'giant' (5). The classification system was constructed not only as a diagnostic tool for the surgeon, but as a means of

${ }^{1}$ University of Western Ontario, Schulich School of Medicine, London; ${ }^{2}$ The Hospital for Sick Children, Division of Plastic Surgery; ${ }^{3}$ Department of Surgery, University of Toronto, Toronto, Ontario

Correspondence and reprints: Dr Ronald M Zuker, Division of Plastic Surgery, The Hospital for Sick Children, Suite 1524 - 555 University Avenue,

Toronto, Ontario M5G 1X8. Telephone 416-813-6447, fax 416-813-6147, e-mail ronald.zuker@sickkids.ca 


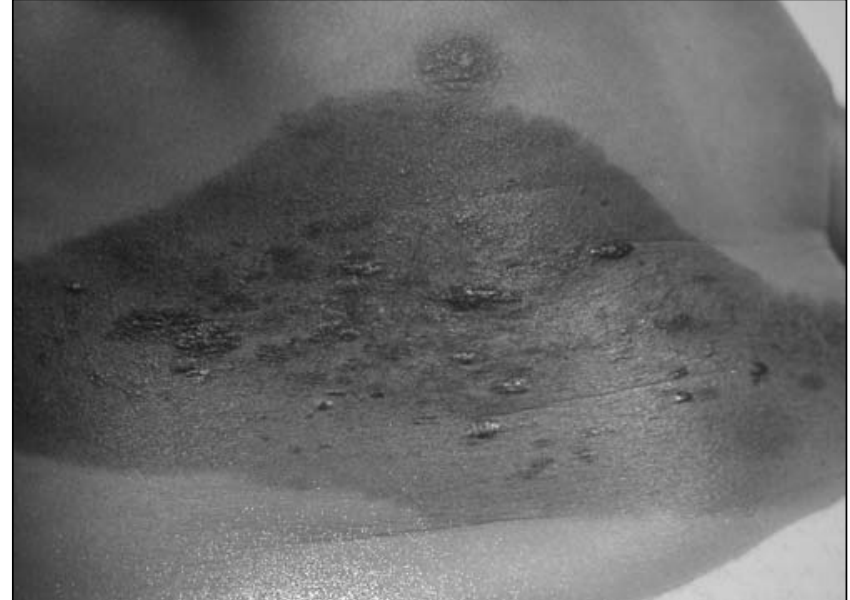

Figure 1) Preoperative photograph of a one-month-old girl presenting with a large congenital nevus over the right breast and abdomen

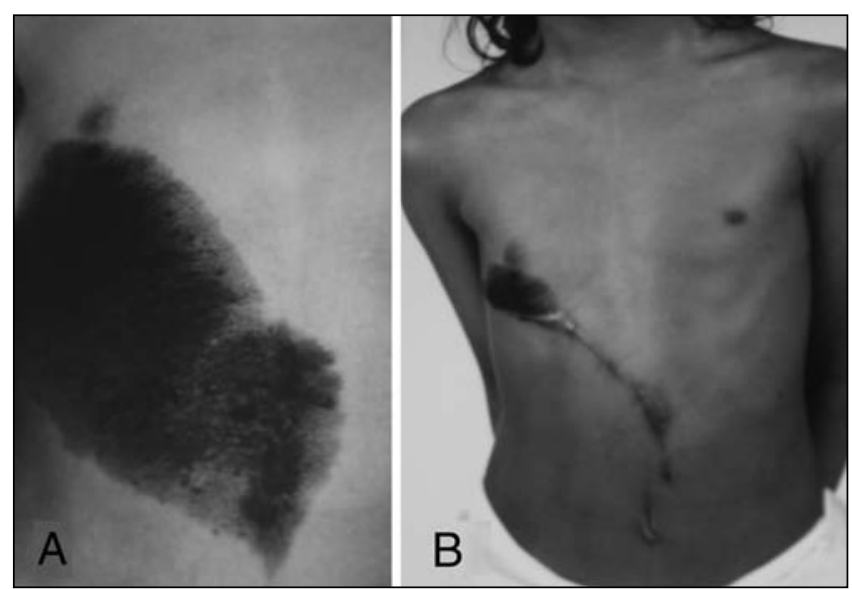

Figure 2) A Preoperative photograph of the patient at six years of age. B Postoperative photographs after excision of the abdominal component of the nevus and coverage with expanded skin

studying malignant potential of lesions of varying size. Recently, there has been a proposal to revise the classification system to take multiple satellite nevi into account (6).

The most frequent neoplasm arising from within a CMN is melanoma, with a reported lifetime incidence of $2 \%$ to $13 \%$. However, these data are controversial (7). There is thought to be a correlation between size of nevi and risk of developing melanoma; the bigger the nevus, the greater the risk (8). It has been reported that when melanomas develop from large CMNs, it is typically before puberty, while small and medium CMNs generally develop melanoma at or after puberty (1). In our experience with hundreds of cases, there has only been one melanoma, that developed in a large CMN of the lower back.

Melanoma is not the only type of malignancy that may arise from a CMN. There have been reports of rhabdomyosarcomas $(9,10)$ found along with malignant peripheral nerve sheath tumours $(11,12)$. Congenital syndromes can be associated with congenital nevi. Neurocutaneous melanosis is a rare but important syndrome associated with large CMNs (13). We have had one such case in a young child that died within weeks of diagnosis.
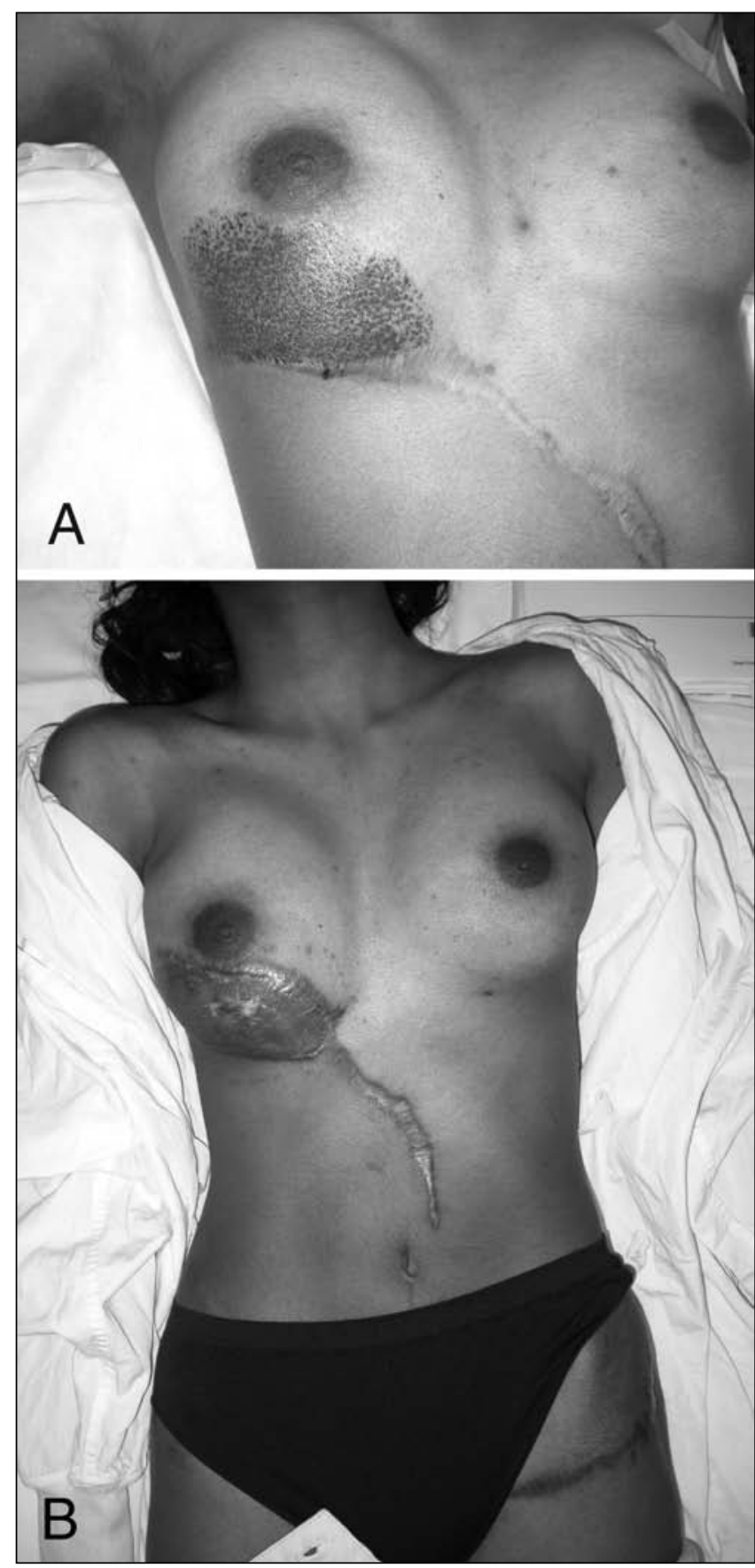

Figure 3) A A preoperative photograph of the patient at 16 years of age with the remaining portion of the nevus before surgery. B Eight-month postoperative photograph after removal of the nevus with placement of a full-thickness skin graft from the left groin

There are a great number of treatment modalities and published algorithms for treatment of congenital nevi. There is, however, very little published on the treatment of congenital nevi involving the breast. Congenital and acquired pediatric breast anomalies have recently been categorized by Sadove and van Aalst (14). Anomalies were classified as 'hyperplastic', 'deformational' or 'hypoplastic.' Manipulation of the breast bud by excising a congenital nevus can produce a 'deformational' 
anomaly that worsens as the breast develops. Scarring can tether the developing breast to the chest wall, creating a secondary contour deformity that can be difficult to address.

The literature contains many treatment options. During the first few weeks of life, there is a natural cleavage plane between the upper and lower dermis. This observation has led to the use of curettage for removal of the superficially distributed nevus cells in CMNs. Curettage is a simple procedure. However, there are risks that must be considered when using anesthesia on a newborn. Moreover, it is still uncertain as to whether the risk of malignancy is reduced, and recurrence is very common (15). Nonlaser dermabrasion is similar in that it reduces pigmentation by removing the epidermis, but it may not prevent the development of melanoma from persistent deeper melanocytic cells (16). Other treatment options include the use of a high-energy pulsed carbon dioxide laser to perform dermabrasion, which is a more controlled method than the nonlaser type (17). Chemical peels have also been used in instances when lesions are too large and would result in unacceptable scars (18). All of these nonexcisional modalities may lead to variable pigmentation, especially in patients with darker skin. Our group has not advocated curettage or dermabrasion for these lesions.

\section{REFERENCES}

1. Tromberg J, Bauer B, Benvenuto-Andrade C, Marghoob AA. Congenital melanocytic nevus needing treatment. Dermatol Ther 2005;18:136-50.

2. Margulis A, Bauer BS, Fine NA. Large and giant congenital pigmented nevi of the upper extremity: An algorithm to surgical management. Ann Plast Surg 2004;52:158-67.

3. Alper JC, Holmes LB. The incidence and significance of birthmarks in a cohort of 4,641 newborns. Pediatr Dermatol 1983;1:58-68.

4. Mizushima J, Nogita T, Higaki Y, Horikoshi T, Kawashima M. Dormant melanocytes in the dermis: Do dermal melanocytes of acquired dermal melanocytosis exist from birth? Br J Dermatol 1998;139:349-50.

5. Kopf AW, Bart RS, Hennessey P. Congenital nevocytic nevi and malignant melanomas. J Am Acad Dermatol 1979;1:123-30.

6. Ruiz-Maldonado R. Measuring congenital melanocytic nevi. Pediatr Dermatol 2004;21:178-9.

7. DeDavid M, Orlow SJ, Provost N, et al. A study of large congenital melanocytic nevi and associated malignant melanomas: Review of cases in the New York University Registry and the world literature. J Am Acad Dermatol 1997;36:409-16.

8. Gari LM, Rivers JK, Kopf AW. Melanomas arising in large congenital nevocytic nevi: A prospective study. Pediatr Dermatol 1988;5:151-8.

9. Hoang MP, Sinkre P, Albores-Saavedra J. Rhabdomyosarcoma arising in a congenital melanocytic nevus. Am J Dermatopathol 2002;24:26-9.

10. Hendrickson MR, Ross JC. Neoplasms arising in congenital nevi: Morphologic study of seven cases and a review of the literature. Am J Surg Pathol 1981;5:109-35.
The most commonly used method for treating CMNs is surgical excision. We used tissue expansion to maximize our patient's aesthetic outcome. Tissue expansion has been used successfully for over 30 years in the treatment of CMNs as well as secondary reconstruction of burn scars (19). The location of the CMN made it amenable to resection and coverage with tissue expanded skin, because it involved the trunk and not the extremities (20). Tissue expansion was performed to allow advancement of local flaps on the trunk so a full thickness excision could be performed. By 16 years of age, the patient had completed breast development and surgical excision was deemed appropriate. She strongly desired to complete the excision. Full-thickness excision was performed again. While we could have potentially used tissue expansion again to resurface the resulting defect, we felt that it would have produced a suboptimal result and deformity of the breast. An alternative would have been serial excision of the nevus, but that would have produced a significant contour deformity with displacement of the nippleareolar complex.

In summary, the patient presented with an unusual surgical challenge. To maximize her aesthetic outcome, an individualized staged approach was used.

11. DiMaio SM, Mackay B, Smith JL Jr, Dickersin GR. Neurosarcomatous transformation in malignant melanoma: An ultrastructural study. Cancer 1982;50:2345-54.

12. Weidner N, Flanders DJ, Jochimsen PR, Stamler FW. Neurosarcomatous malignant melanoma arising in a neuroid giant congenital melanocytic nevus. Arch Dermatol 1985;121:1302-6.

13. Foster RD, Williams ML, Barkovich AJ, Hoffman WY, Mathes SJ, Frieden IJ. Giant congenital melanocytic nevi: The significance of neurocutaneous melanosis in neurologically asymptomatic children. Plast Reconstr Surg 2001;107:933-41.

14. Sadove AM, van Aalst JA. Congenital and acquired pediatric breast anomalies: A review of 20 years' experience. Plast Reconstr Surg 2005; 115:1039-50.

15. De Raeve LE, Roseeuw DI. Curettage of giant congenital melanocytic nevi in neonates: A decade later. Arch Dermatol 2002;138:943-7.

16. Rompel R, Moser M, Petres J. Dermabrasion of congenital nevocellular nevi: Experience in 215 patients. Dermatology 1997;194:261-7.

17. Reynolds N, Kenealy J, Mercer N. Carbon dioxide laser dermabrasion for giant congenital melanocytic nevi. Plast Reconstr Surg 2003;111:2209-14.

18. Hopkins JD, Smith AW, Jackson IT. Adjunctive treatment of congenital pigmented nevi with phenol chemical peel. Plast Reconstr Surg 2000;105:1-11.

19. LoGiudice J, Gosain AK. Pediatric tissue expansion: Indications and complications. J Craniofac Surg 2003;14:866-72.

20. Pisarski GP, Mertens D, Warden GD, Neale HW. Tissue expander complications in the pediatric burn patient. Plast Reconstr Surg 1998;102:1008-12. 